\title{
Biofuel Benefit or Bummer? A Review Comparing Environmental Effects, Economics, and Feasibility of North American Native Perennial Grass and Traditional Annual Row Crops When Used for Biofuel
}

\author{
Jacqueline Jacot $^{1, *}$, Amber S. Williams ${ }^{2}$ (I) and James R. Kiniry ${ }^{2}$ \\ 1 Oak Ridge Institute for Science and Education, 808 East Blackland Rd., Temple, TX 76502, USA \\ 2 Grassland, Soil and Water Research Laboratory, U.S. Department of Agriculture-Agricultural Research \\ Service (USDA-ARS), 808 East Blackland Rd., Temple, TX 76502, USA; amber.williams@usda.gov (A.S.W.); \\ jim.kiniry@usda.gov (J.R.K.) \\ * Correspondence: jacqueline.jacot@usda.gov
}

\section{check for}

updates

Citation: Jacot, J.; Williams, A.S.; Kiniry, J.R. Biofuel Benefit or

Bummer? A Review Comparing

Environmental Effects, Economics, and Feasibility of North American Native Perennial Grass and Traditional Annual Row Crops When Used for Biofuel. Agronomy 2021, 11, 1440. https://doi.org/10.3390/ agronomy11071440

Academic Editor: Danilo Scordia

Received: 7 June 2021

Accepted: 17 July 2021

Published: 20 July 2021

Publisher's Note: MDPI stays neutral with regard to jurisdictional claims in published maps and institutional affiliations.

Copyright: (C) 2021 by the authors. Licensee MDPI, Basel, Switzerland. This article is an open access article distributed under the terms and conditions of the Creative Commons Attribution (CC BY) license (https:/ / creativecommons.org/licenses/by/ $4.0 /)$.

\begin{abstract}
While biofuels have been touted as a benefit for growers-with the ability to be planted on marginal lands, for improved wildlife habitat, to sustain soils, and to reduce runoff-there remains to be a general summary of how beneficial they really are. This paper aims to review the environmental effects, feasibility, and economic aspects of using native perennial grasses in North America as biofuels as opposed to traditional annual crops. The Scopus database was used to search for manuscripts relating to each topic. In some instances, very few results appeared, so a second database, Digitop, was also used. Native perennial grasses have been found to sequester carbon and cultivating them can create a carbon sink in the soil. Overall, wildlife benefit more by having native perennial grass for biofuels planted than annual maize and having fewer harvests a season is better for wildlife over the entire year. Economically, growing native perennial grasses can be advantageous especially on marginal land, where it has a comparatively high yield. Although the second-generation biofuel supply chain is susceptible to changing market prices, it can be made more resilient and has advantages, for example resistance against the impacts of drought. Although there are many cultivars to choose from, factors like climate, soil, and genetics can provide pertinent information to match each specimen's ideal growing conditions to the right location.
\end{abstract}

Keywords: biofuels; perennial grasses; second generation biofuels; bioenergy crops

\section{Introduction}

Biofuels have been touted as a benefit for many of its qualities: for growers, some biofuels can be planted in marginal lands and as an extra source of income; for wildlife, biofuels make a better habitat alternative to annual crops; for ecosystem services, biofuels sustain soils and reduce runoff. Is this really the case, or are biofuels a bummer instead of a benefit? This paper is a review of using native perennial grasses in North America as biofuels. Environmental effects, feasibility, and economics will be discussed.

Biofuels have been in use since prehistory in the forms of firewood, wood chips, and wood charcoal [1]. Biofuels can be a liquid, solid, or gas and can fall into the following categories: biodiesel, bioethanol, solid biofuels, biogas, biohydrogen, biobutanols, or biooils $[1,2]$. Solid biofuels include firewood and charcoal, which have provided energy for people since antiquity [1]. Biooils, like palm oil and sunflower oil, are well known alternative energy sources, but bioethanol can be derived from many kinds of cultivated biomass including lignocellulosic materials and sugarcane. Brazil is one of biofuel's success stories, with bioethanol from sugarcane encouraged as a fuel for cars since the 1970's [2]. By the 1990's, maize (Zea mays) was the preeminent prospect for biofuels in the United States, a national initiative to reduce dependence on foreign oil led to a rapid transformation in 
the American Midwest, as maize production increased yearly, requiring more and more land [3-5]. By 1991, scientists realized switchgrass (Panicum virgatum L.) was a potential bioenergy source [3]. Today, maize remains the primary biofuel feedstock in the US, but $\mathrm{C}_{4}$ native grasses still have the potential to supplement or supersede it in the effort to reduce reliance on fossil fuels. Of the $C_{4}$ grasses, switchgrass is a front-runner [4]. It is compatible with current agricultural practices and has a high biomass production capability, even when compared to other grasses like big bluestem (Andropogon gerardii Vitman (Poaceae)) [3]. Biofuels have a number of benefits compared to conventional fuels; although it depends on type and how they are used, they can be more efficient and pollute less [6,7]. In turn, native perennial grasses have several advantages over other types of biofuels. Introduced species such as Miscanthus sp. have the ability to become invasive [8-10] creating other environmental issues. Annual crops, such as maize, take more effort and resources to establish every year and provide fewer ecosystem services compared with perennials, including increased runoff, nutrient loss, and soil erosion [11-15]. Native perennial biofuels perform better than annual biofuels in terms of positively impacting wildlife, however, if native habitat was removed to plant the perennial biofuel wildlife may be negatively impacted [16-19]. The type of biofuels and location on the landscape are vital components to successful biofuel plantings, as ecosystem services and wildlife benefit from native perennial plants in the right settings [14,20-22].

Economically, native perennials will cost less in the long term to maintain than annual crops as they only need to be planted once, can be grown in marginal land, and annual inputs, such as pesticides, will be minimal to none comparatively. While demand for biofuels currently outpaces supply, with proposed government incentives, the supply chain is expected to improve [23]. Currently, direct perennial biomass crop profits are below that of traditional crops when compared ton to ton, however when calculating other factors such as ecosystem services to costs and benefits or planting native perennial biofuel to low yielding areas are considered, producers can expect a net gain in revenue [15,22].

In this article, native perennial biofuels are discussed as an alternative to traditional annual row crops in ecosystem services such as soil and wildlife impacts, economic viability and supply chain, and overall feasibility.

\section{Materials and Methods}

The Scopus database was used to search for manuscripts relating to each topic. In some instances, very few results appeared so a second database, Digitop, was also used. Table 1 lists the search terms used for the topics, the date the literature search was performed, the total articles that resulted, and the number of relevant articles. Articles were discarded if, upon further reading, the criteria "North American native perennial grasses" was not discussed. The database search was also supplemented with articles suggested by colleagues or Google Scholar. These last few are not listed in the table but are cited when discussed.

Table 1. Database search results for manuscripts by topic. Scopus is the primary database shown, if the secondary database Digitop was also used, the number of results is listed second.

\begin{tabular}{ccccc}
\hline Topic & Search Terms & Date Searched & Results & Relevant \\
\hline \multirow{3}{*}{ Environmental Effects } & Soil Carbon + Biofuels + Perennial Grass & 5 January 2021 & 69 & 49 \\
& Wildlife + Biofuel + Perennial Grass & 17 December 2020 & 9,59 & 8,13 \\
& Agriculture + Biofuel + Perennial Grass + Land Use & 18 December 2020 & 57 & 24 \\
\hline & Biofuel + Perennial Grass + Fossil Fuels OR Fossil & & & \\
& 5 January 2021 & 41 & 20 \\
Economics & Biofuel + Perennial Grass + Supply Chain & 5 January 2021 & 7 & 5 \\
& Biofuel + Perennial Grass + Economic Demand & 5 January 2021 & 10 & 5 \\
\hline
\end{tabular}

The search for research discussing the role of perennial bioenergy grasses on soil carbon occurred on 5 January 2021 using the SCOPUS search engine. The terms used 
were "((Soil carbon) AND biofuels AND (perennial AND grass))" which yielded 69 results. Ultimately, only 49 were within the scope of this review. By focusing on studies related to the continental United States and on perennial grasses used for biofuels, research involving annual crops, nonnative plants, or studies that focused on Europe or Hawaii, were excluded. Two studies were also excluded because they focused solely on model validation and provided no new information about soil carbon under these circumstances. Despite these limitations, the research focused on a wide breadth of carbon availability and management situations.

To discuss the economics and supply chain aspects of native perennial biofuel grasses two searches were conducted on 5 January 2021 using the SCOPUS search engine. The first, "(biofuel AND (perennial AND grass) AND (economic AND demand))", yielded 10 results. Of these ten, five were excluded for being unrelated to economics or outside the geographic scope of this paper. The next search, "(biofuel AND perennial AND grass) AND \{supply chain\})" yielded seven results, of which two were excluded for being inaccessible or detailing an unrelated topic. Several other pertinent papers were considered after recommendation from informed colleagues.

\section{Results}

\subsection{Environmental Effects}

\subsubsection{Soil Carbon}

Soil carbon is affected by a myriad of environmental factors like microbial communities, soil type, or crop management; So, when it comes to the ways in which perennial grasses can alter soil carbon levels, it varies widely by circumstance [24-74]. Ultimately, there are several conclusions which can be drawn from the literature regarding native perennial grasses used for biofuels and their impacts: land use change matters, different crops alter soil in varying ways, diversity plays a role, and that time and depth are important but sometimes overlooked factors [24-74].

When converting land to bioenergy crops, it matters what the land is being converted from. For example, if being changed from a forest to crops there will likely be an initial loss of soil carbon, but if converting from a monoculture maize crop to perennial biofuel, then there will likely be an increase in soil carbon. Of the papers that specifically addressed land use change, three concluded that to change a grassland to a monoculture of grasses for biofuels would cause a net decrease in soil carbon [29,34,42]. Two did not address grasslands or concluded that there was no significant change in carbon flux [35,56]. However, when the land use change occurs in an agricultural site currently growing maize or another crop, switching to a perennial grass was found to either maintain or increase soil carbon. This was extrapolated upon in seven other reports $[27,28,33,38,45,51,57]$ which also detailed that switchgrass or perennial biofuel grasses sequestered more soil carbon than maize or maize- soybean (Glycine max (L.) Merr.) plots. Two of these studies focused specifically on carbon in aggregates and both found that switchgrass contained more carbon and stabilized aggregates better than maize did, which brings more benefits to the soil [28,33].

Perennial grasses also sequester varying amounts of carbon. Bandaru et al. [26] found that switchgrass sequesters an average of $0.23 \mathrm{MgC} \mathrm{ha}^{-1} \mathrm{yr}^{-1}$, but had wide variations in their simulations based on their study region. Another study by Das et al. [31] concluded that switchgrass sequestered more carbon than sorghum or even a prairie mix. Adkins et al. [47] found that "big bluestem dominated plots exhibited greater soil carbon accrual relative to stands dominated by switchgrass and mixed-species treatments".

Overall, diversity is beneficial for soil carbon. Fornara and Tillman [42] explored this in detail and found that "more soil carbon accumulates at higher diversity". Although their plot of $\mathrm{C}_{4}$ grass monocultures had qualities that should foster soil carbon accumulation, it only had a third of the soil carbon as a plot with fifteen additional species. Legumes and $\mathrm{C}_{4}$ grass especially had a positive effect on soil carbon. Similarly, Sprunger et al. [29], found that diversity encouraged fine root growth, a condition which fosters the accrual of 
soil carbon. Of the four papers on this topic which examined diversity, three agreed that diversity increased, or led to conditions which increase, soil carbon [29,42,47,71].

It takes several years for bioenergy crops to become a carbon sink. As explained by Abraha et al. [46], when grasslands are converted to crops, sequestered soil carbon is lost upon conversion. However, it is assumed that when those new crops are used for biofuels, that any greenhouse gases will be saved by utilizing ethanol rather than petroleum products. The 52 studies reviewed ranged from two to thirty years and varied in methodology. In 2018, Abraha et al. [51] found that a grassland converted to a perennial monoculture would take fourteen years to become a carbon sink. Then one year later, Abraha et al. [46] used a measurement called Global Warming Impact to argue that a former grassland converted to a switchgrass field would pay back its carbon debt in eight years or, if it was grown on former agricultural land the switchgrass field would become a carbon sink in two years.

Depth is also discussed as an important factor for soil carbon accumulation. Most studies limited their scope to only the top ten centimeters of soil, however Follett et al. [54] found that over half of their total increase in soil carbon was below thirty centimeters of soil. Gauder et al. [50] found significant results as deep as ninety centimeters deep. This may be due to the deep roots of native perennial grasses and the complex ways they interact with other species, whereas most annual crops have much shallower root systems.

Although the studies reviewed contained a variety of hypotheses, scopes, methodologies, and techniques, the results were uniform in their complexity. Almost all of the papers included qualifiers for land use change, management techniques, soil conditions, and length of time. Twenty-two were able to clearly state that under their test circumstances perennial biofuel grasses increased soil carbon $[26,27,29-32,38,39,42,45-47,50,51,54,60,61,64,66,68,71,73]$. Two studies conclusively said that soil carbon decreased with the introduction of these grasses, however both of these studies focused on the role of soil microbes on soil carbon stocks [25,40]. Sixteen studies came to an ambiguous conclusion $[28,33,34,36,41,49,55-58,62,63,67,69,72]$. This is largely due to the aforementioned natural variation on this topic. One found that soil carbon levels were consistent despite change in crops, and five found either no significant difference or inconclusive answers to their questions $[36,41,56-58,69]$. Ten were studying very specific aspects of soil carbon, like fertilizer application or harvest dates, which were informative about how carbon behaves but were not a conclusive yes or no to if these grasses increase or decrease soil carbon $[28,34,47,49,55,57,60,63,66,67]$. To draw conclusive answers on how perennial biofuel grasses affect soil carbon is a multi-faceted question with highly variable answers. Although considerations should be taken for a given area's environment and land use change, native perennial grasses grown for biofuels preserve soil carbon, with an especially notable effect on marginal soils and former monoculture agricultural soils, according to most studies we reviewed.

Besides soil carbon, which is an important topic related to climate change, perennial grasses have advantages over annual crops in terms of impacts on ecosystem services to soil and waterways. Establishing a crop usually requires herbicide application, soil tillage, and soil compaction during the planting process, causing erosion and added runoff into waterways. Exposed soils erode by wind and water losing the more fertile top layer. Water runs off faster leaving little time for absorption by the soil. The runoff also carries with it sediment, pesticides, and fertilizers into the waterways. The sediment causes the water to be more turbid changing water temperature and creating visibility issues for animals along with filling in waterways reducing water storage and habitat. Pesticides spread to waterways pollute water supply for people, plants, and animals. Fertilizer input leads to excess algal blooms, and hypoxia creating dead zones where aquatic animals cannot breathe. Multiple studies have shown that besides the reduced impact of establishment (one year verses repeated annual disruptions), perennial grasses also reduce erosion, water runoff, sedimentation, and pesticide runoff, and increase soil's capacity to hold moisture $[8,11,75,76]$. 


\subsubsection{Wildlife}

Wildlife's presence, abundance, and diversity depend on the type of land use present, specifically vegetation. Vegetation determines if an animal wants to stop during migration, can find food or shelter in the space, or if the area can be used for breeding displays or nesting. Vegetation also determines other landscape wide impacts on the surroundings. Some animals will not use a space if the ideal habitat is too small or borders a habitat type they avoid. Vegetation also impacts water runoff into rivers, which could also transport nutrients, toxins, or soils into the water body. Loss of sediment can also be harmful for the upland, as less topsoil remains for plants to take root. Keeping this in mind, how do native perennial grass biofuels impact wildlife? The answer, as often biologists will reply, is it depends. As stated by Fargione et al. [8], the bioenergy crop and production operations have many components which impact the quality of wildlife habitat including: location on the landscape, what type of land the crop is replacing, harvest height, harvest timing, harvest frequency, vegetation type and diversity, among other factors. Biofuel crop choice and location on the landscape play a role in wildlife biodiversity and ecosystem services [22].

Literature search results showed eighteen papers saying that either diversity, abundance, richness, or presence of insects, birds, and other vertebrates were positively impacted by having native perennial biofuels planted $[8,14-19,21,22,77-85]$. The differences between how the wildlife reacted to native perennial biofuels depended on what the previous land use was, which perennial biofuel was planted, and biofuel harvest dates. All the manuscripts indicated native perennial grass biofuels had more favorable impacts on wildlife than that of maize or annual biofuel fields. If comparisons were made between the biofuel and the native habitat or if the biofuel was a monoculture vs. a heterogenous field, results were more mixed. Helms et al. [84] states that monoculture switchgrass compared with prairie had no difference in ant activity, while Lee et al. [85] states that pollinators and predatory insects abundance in switchgrass compared to mixed grass varied by season and richness was frequently higher in the mixed grass [84,85]. Robertson et al. [78] summarized grassland bird richness in migration and breeding are comparable for switchgrass and mixed grass, but not as rich as native prairies. Conkling et al. [79] states that grassland birds nest survivability has no difference between switchgrass and mixed grass, but nest density and productivity were higher in mixed grass than switchgrass. Harvest frequency also affected wildlife differently. Roth et al. [81] found that August harvesting of switchgrass resulted in different grassland bird species nesting the following spring, specifically that species who preferred taller denser nesting sites used the unharvested fields while birds preferring shorter grasses nested in the new switchgrass regrowth. They recommend varying the harvests so both types of fields are available for nesting season. Harvests on critical habitat may be restricted by law [86]. Conkling et al. [79] found that harvest frequency had varying effects on dickcissel nest survivability: no effect, nest abundance, and nest productivity which were both $10 \%$ greater in single harvest plots. Lee [85] et al. found that harvest frequency had no effect on insect abundance or diversity. Overall, wildlife benefit more by having native perennial grass biofuels planted than annual maize and having fewer harvests a season.

\subsubsection{Land Use}

With the aforementioned positive environmental effects compared to annual crops, the next logical question becomes how will native perennial biofuels fit on the landscape? The often sited 'trilemma' is the competition for land use by food, fuel, and environment. For example, in tropical areas with a rainforest that had become a monoculture palm oil plantation, the habitat loss caused by that transition led to biodiversity loss as well. This effect was exacerbated when commodity prices increased and created an incentive to expand production [87]. This competition-created incentive to change non-cropland to cropland is called indirect land use change and it releases carbon stored in soils and biomass [88]. This land displacement can add up and is not always contained in the local 
area or even national borders [89]. When cropland is transformed in one place, food will be grown elsewhere and imported. In fact, the greenhouse gas emissions can be intense enough to undo carbon savings from avoiding burning conventional fuels, meaning it is a priority for policymakers and researchers to solve [89]. The goal is not to displace environmentally critical habitats, lose food production, or replace forests. Solomon [90] says that the competition with food versus fuel is higher when growing traditional crops for biofuels (maize, rapeseeds (Brassica napus L.), sugarcane (Saccharum species), etc.) and that cellulosic ethanol crops are the only biofuel with potential to be produced and consumed sustainably.

Native perennial bioenergy crops are another source for the fuel component, but much land has already been devoted for other purposes. Wright and Wimberley [91] have said that in the Western Corn Belt states from 2006 to 2011 grassland has been converted to maize and soybean fields at a rate comparable to deforestation in Brazil, Malaysia, and Indonesia. Mladendoff et al. [92] has said that from 2008 to 2013, 37\% of the nonagricultural open land has already been converted to agriculture in the Great Lake states. Deen [93] says there is no new land available in Ontario for dedicated biofuel crops. A very different situation exists if, instead of croplands, native prairies or forests are converted to monoculture biofuel. However, we are not addressing those situations in this study.

The type of biofuels and location on the landscape are vital components to successful biofuel plantings, as ecosystem services and wildlife benefit from native perennial plants in the right settings [9,15-17]. Schilling et al. [94] used the Soil and Water Assessment Tool (SWAT) model to simulate a region of the Corn Belt in Iowa in which some land dedicated to cultivating annual maize crops were converted to annual grasses. They found that increased perennials also increased evapotranspiration, decreased loss of nonpoint source pollutants, and decreased water yield compared to when maize production was increased.

Several potential solutions have been proposed. To combat indirect land use change, policy changes such as a carbon price policy that penalizes fuels with a higher carbon intensity or certifying lower impact fuels and restricting the development of non-certified fuels would make cellulosic feedstocks more appealing [88]. Deen [93] suggests putting the perennial biofuels in a 5-year rotation with annual crops so the perennial biofuel yields that are harvested annually will be higher than if the crop was grown on marginal soils. Others suggest replacing the current annual biofuel crops, with perennial biofuels so no new land is lost. Pairing biofuels with other efforts like improving efficiency of technology is also given great importance [89].

Utilizing spaces that are not typically used for crop production is an option for some grasses such as switchgrass. The literature search results include fifteen papers mentioning growing perennial biofuels on marginal soils [59,76,77,90-93,95-102]. These are areas where it is suboptimal for crop production. Marginal lands include abandoned or degraded croplands, edge of field, reclaimed mining lands, urban marginal sites, and soils which are flood or drought prone, rocky, sandy, eroded, compacted, saline, acidic, or contaminated [76]. Some farmers are planting traditional crops in marginal soils resulting in lower yields or collecting crop insurance if they fail. By replacing the low or nonproductive annual crops with switchgrass or other native perennial grasses they will have a more consistent income for these fields and reap the environmental benefits. With maize and other annual crops planted in the optimal field settings, they will have a higher yield and the suboptimal fields which were used can be planted with switchgrass or other native perennial grasses. Issues that arise when using marginal lands can include lower yields, or difficulty establishing plants. However, many of the native perennial grasses used for biofuels are better adapted to these areas than their traditional annual crop competitors. Marginal lands may need amendments to increase production potential, but whether this is required for economic profitability is highly variable depending on the site's characteristics [76].

One suggestion is to harvest Conservation Reserve Program, or CRP, fields or replace the main plant with a higher producing native perennial grass. However, the effect of this 
land use change could have a negative impact on wildlife. CRP is a government funded program which pays landowners to keep the land out of crop production for ten to fifteen years and plant environmentally beneficial species instead. It has been estimated that CRP land alone could provide $40 \%$ of the biomass needed to meet current Renewable Fuel Standard goals [103]. However, this is an example of indirect land use change, one of the bigger challenges to biofuel adoption and it directly contradicts the intentions of the CRP program. A mid-2000's congressional testimony from the mid-2000's suggested a similar idea to increase maize production for biofuels [94]. Behrman et al. [103] posits that, because these lands are often subject to erosion, the low-quality soil means it is difficult to know how much biofuel can be produced and its effects on the animal residents of these "plant diverse communities". Also, Pritsolas and Pearson [104] found that their simulations predicting the effects of converting protected grasslands back to agricultural lands likely could not identify the impacts within an existing agricultural footprint. If only CRP land was used to cultivate switchgrass, the projected amount of land needed to reach the current Renewable Fuel Standard's goal exceeds the amount of land needed to reach the same amount if farmers were not limited to CRP lands. Behrman et al. [103] argued that the best balance between biodiversity conservation and biomass yield can be struck when some CRP lands can be utilized as well as other lands. Evans et al. [105] modeled land use conversion for switchgrass while keeping biodiversity in the US using former or current cropland, CRP, and pastureland and found the most suitable land to be most beneficial to at risk wildlife and profitable for farmers is outside of the Corn Belt.

An additional recommendation is to keep native grasslands and pastures and use them for biofuels instead of planting new monocultures of perennial biofuels. This recommendation would prevent the economic and environmental costs of field preparation, planting, establishment, and land competition. Note that when harvesting a grassland care must be taken as to timing and frequency so as to not hinder wildlife populations, or damaging the plant stands by over harvesting, while still attaining an acceptable yield.

\subsection{Economics}

\subsubsection{Economics of Native Perennial Grass Biofuel vs. Annual Agriculture}

The economic status of biofuel crops is multi-faceted and subject to frequent changes. The factors that determine if biofuels become widely use are economic. Even if renewable energy mandates were implemented, cost would determine the technology, crops, and production strategy [4]. Tim van der Weijde et al. [106] said this quite succinctly when they wrote, "It is unlikely that all the prerequisites for the sustainable and economic production of biomass for a global cellulosic biofuel industry will be fulfilled by a single crop". While some research accounts for or speculates about the possible upcoming technological advances in the biofuel industry, whatever changes do come will alter the success of a coordinated shift to renewable energies [23,41,44,46,52,64,77,80,92,93,105-125]. These technological developments may include advancements in breeding, improvements in residue collection, new methods of increasing yield, and increased efficiency in supply chains and transportation. Other than new innovations, the variables with the largest influence on the economic sustainability of biofuels are biomass yield, land availability, and land cost.

One of the great assets of native perennial biofuels is that it can grow on land that is considered marginal. In areas like The Corn Belt, this reduces competition for land with other, more lucrative crops. In fact, it is likely that the cultivation of biofuel crops would be best suited for areas outside of the Corn Belt because of the lower cost of land and the comparatively high yield of these crops on marginal soils. It is important to note that, despite their high yields on marginal soils, biofuel crops often compete against each other for space on those marginal soils. This means that a high-yielding non-native species, such as miscanthus, may seem more appealing than a native crop like switchgrass.

In 2011, Khanna et al. [37] concluded that, "Switchgrass can make a substantial contribution to total biomass if its yields are high, and costs of production are low .... very 
high biomass prices would be needed to make it viable under current assumptions about yields and costs of production". When considering native grasses as a potential crop, it is astute to remember that 2011 was a decade ago in a rapidly changing industry. In fact, Scheffran et al. [23] argued two years prior that biofuel supply lags behind its growing demand, which temporarily artificially inflates prices. They concluded that a "high rate of initial demand may be needed to stoke market acceptance of biomass crops" and that once farmers grow more biofuels, the price can be expected to fall. We now see that market forces, rather than regulation is determining the shape of the biofuel economy. Much like its ecology, the status of the currently biofuel economy is multi-faceted and complex. In 2020, cellulosic ethanol production would provide 12.6 billion dollars in annual benefits to US consumers. It would add over 20,000 agricultural jobs, at the expense of other sectors, and lower crude oil prices [126].

There are other economic factors to consider besides direct profit from growing perennial biofuels. One commonly noted advantage of all biofuels is that, in addition to their environmental benefits, when they replace fossil fuels, they reduce greenhouse gas emissions and can play a role in lessening the impacts of climate change. Yet their uses and impacts are entwined with economics. Hudiberg et al. [44] found that projected emissions decreased by about $7 \%( \pm 2.5 \%)$ when cellulosic biofuels displaced gasoline and biofuel crops stored carbon in the soil. Yet, the emissions fell even further, about $12.3 \%$ $( \pm 3.4 \%)$, when accompanied by a tax credit. In 2019, Mishra et al. [15] used the SWAT model to estimate the values of ecosystem services and found that marginal lands in the Midwest have the potential for "The estimated annual values of nitrate and sediment reduction attributed to bioenergy crops range from $\$ 38$ million to $\$ 97$ million and $\$ 16,000$ to $\$ 197,000$, respectively. The annual value of carbon dioxide emission reduction ranges from $\$ 1.8$ million to $\$ 6.1$ million based on the initial crop rotation pattern.". Providing further evidence that switchgrass, especially on marginal lands are a boon to both the environment and the economy.

\subsubsection{Supply Chain Capabilities}

This volatility in market price can be considered a vulnerability for the biofuel supply chain. Like all forms of energy infrastructure, the supply chain for biofuel derived from crops has some risks and opportunities. In 2014, Langholtz et al. [127] described the present weaknesses in the biofuel supply chain, this included: changes in market prices, as well as decreases in production and/or supply, and weaknesses in the existing supply chain infrastructure. In addition, the intensifying severity of climate change reveals new susceptibilities such as weather risk to croplands and increased pests and diseases.

Reduced supply caused by seasonality or a shortage can cause higher biomass prices. Zhu and Yao [128] recommended utilizing a mix of biofuels in order to avoid such issues. Although they favored a mix of switchgrass, maize stalk, and wheat straw, switchgrass in particular has several advantages in the face of climate change. Upland cultivars of switchgrass showed no detrimental response to simulated climate change, although lowland cultivars were limited by warmer temperatures [129]. Switchgrass' long roots allow it to draw water from deep in the soil, which makes it more resistant to drought, the greatest climate-based threat to biofuel farming. This was further explored by Hawkes and Kiniry [130] where it was found that switchgrass stands can recover from a drought with a year of normal rainfall, especially if the plant were already established when the drought began.

In addition, as a perennial plant, yearly replanting is not required and there is some flexibility in planning for harvest. Biofuel grasses can be grown in a larger geographical area than other crops and, although this is an asset it can mean longer, and more costly transportation logistics, somewhere between $13.2 \%$ and $31.1 \%$ of total cost according to Liu et al. [102]. Both this and the ways harvest dates vary by geographic location, are reasons to advocate for smaller, regional supply chains. Kim et al. [131] used a hybrid simulation model was used to identify ideal locations for biomass storage facilities. They 
found that transportation costs decreased as the number of available storage facilities increased, but holding costs increased if supply surpassed demand.

Langholtz et al. [127] made four specific recommendations for reinforcing biofuel supply chain management: (1) increase bulk density by converting biomass into a uniform commodity feedstock thereby reducing transport costs, (2) increase storage stability allowing for feedstock stockpiles, (3) develop grading scheme or standard for feedstock, and (4) utilize debris from forests and built environments to increase capacity. Others have noted the ability for job creation that biofuels can bring and the potential for regional supply chains to protect against shortages or price increases [113,132].

Seasonality may not be as large an issue as anticipated as a study taking place in Nebraska found that "sufficient quantities of biomass could be produced from maize stover and switchgrass ... to support year-round cellulosic ethanol production at current feedstock yields, sustainable removal rates and bioconversion efficiencies" [133].

However, assessing the current economic state of biofuel crops in the US does leave us with the following conclusions: the ideal strategy for economically sustainable growth of biofuels will be a tradeoff between yield and the opportunity costs of the land, biofuel supply has historically lagged behind demand, and biofuel supply chains would benefit from increased resiliency especially with a focus on climate change [102,127,128,132,134-136].

\subsection{Feasability: Biofuel Selection \\ Right Plant for the Right Place}

The key to successful plantings of native perennial grass for biofuel is to use the right plant for the right place. Whether a plant is a feasible option depends on several key factors: climate, soil, plant selection, genetics, and variety. These factors go hand in hand for determining success at a given location. The other important thing to consider is place on the landscape. As discussed above, for wildlife to benefit certain areas are better or worse places for these fields depending on proximity to resources, type of biofuel and harvest schedules, while for current agricultural field benefit the edges of fields, marginal land or corners not covered by the center pivot may be best. All plants have ideal growing conditions, and this is no different for biofuels. Certain aspects of the plants make it better suited for different situations. To be most successful it depends how the grower wishes to use this biofuel. Is it the main crop, a supplement, something to grow where crop yields are inadequate, or a new grassland? Though other grasses or mixed grasses will also be successful in their place, our feasibility example for North American native perennial grass to use as a biofuel will focus on switchgrass as more studies have focused on it than many of the other potential candidates.

Switchgrass has a wide distribution in North America from Canada to Mexico east of the Rocky Mountains growing best east of the 100th meridian [137]. That being said, the location on the landscape determines the climate, soil, and land use feasibility. Switchgrass is able to be successful on marginal soils, in a mix, in a monoculture, edge of fields such as buffer strips or corners not covered by center pivot, and in a range of climates such as surviving periodic droughts or floods. In any case, the proper variety of switchgrass should be used for the location.

As shown by Behrman et al. [138]. Behrman et al. [139]; Evans et al. [105]; Stoof et al. [101]; Blanco-Canqui [76]; Kim et al. [140]; and Kim et al. [129] where you are can greatly effect yields. Location is a prominent factor of yield. The further switchgrass is planted from the variety's origin the less yield [141]. Likewise, the closer to the variety's origin more switchgrass will yield [140]. Latitude and longitude also affect yield [129]. Location on the continent is one aspect, but other factors will also contribute to the chosen plant success or failure, such as climate, photoperiod, and soil.

Climatic factors play a role in switchgrass variety success due to temperature extremes or precipitation events. Minimum temperature affects yields [129]. In colder climates, more upland varieties were successful while 'Alamo' had a lower yield, and in hotter climates, 'Kanlow' (a lowland variety originating further north than 'Alamo') had less 
yield [141]. While temperatures have an effect, Behrman et al. [139] also mentions that photoperiod does as well, as northern varieties planted in the south do not catch up to those originating in the south. A study of ten different native perennial grasses, including switchgrass, showed that overall soil and rainfall effected yields [142]. Switchgrass is also adaptable to variability in precipitation as previous year rainfall helps to sustain switchgrass through drought years, and total precipitation affect yield [129,130]. Again, variety is important as amount and timing of precipitation affect yields more on upland than lowland varieties [143].

There are many cultivars that have been developed from the standard native switchgrass. Many cultivars developed naturally but some have been bred to select for certain characteristics [3]. These were created to emphasize yields in varying locations, but they can all be grouped into either the upland or lowland category. The upland varieties are hexaploid or octoploid and grow in drier soils while the lowland varieties are tetraploid and grow on wetter soils thanks to the presence of aerenchyma calls in the stems and roots [76]. Lowland types were found to have higher yields in south, and upland types had higher yields in the north possibly because the upland types wait to emerge protecting them from frost $[129,138,139]$. Soil type, precipitation, and latitude also interact with upland and lowland ecotypes to yield different results [144].

Even in unideal conditions you can still achieve usable yields. Marra et al. [95], showed that switchgrass can grow on reclaimed mining soils. The reclaimed mining soil site with added crushed rock yielded lower than economically viable, yet the site with added topsoil and treated municipal sludge, though $50 \%$ of the yield shown on agricultural soil, had economically viable yields. The rocky site had highest yields using the switchgrass variety Shawnee, while the site with added topsoil and treated municipal sludge had the highest yields with the switchgrass variety Cave-in-Rock. With addendums and proper variety selections, growing switchgrass in these conditions was economically feasible. Gu and Wylie [13] shows the potential for switchgrass on marginal cropland as waterway buffer strips planted on highly erodible soil in croplands using modeling efforts including topographic maps, existing croplands, waterways, and biofuel production estimates in eastern Nebraska. They state that 1.2 million metric tons could be harvested for biofuels while still providing valuable ecosystem services to the landscape. Two other papers discuss modeling using land use data, satellite imagery and plant modeling to show how it is feasible to supply different types of existing refineries with switchgrass for biofuel. Uden et al. [133]) shows how it is feasible to replace marginal cropland (such as center pivot corners) with switchgrass in Nebraska, and thereby give producers ability to still get profits and supply the cellulosic ethanol factory with year-round vegetation when combined with other local biofuel sources. Aranguren et al. [145] showed switchgrass is able to be grown in sufficient quantities regardless of predicted climate change in the area and is a logistically viable biofuel source for co-firing coal fired power plant in southern Texas.

Which perennial grass or mixture is chosen depends on the grower's intended results. This could be: (1) maximum yield with minimum input, (2) survivability in unideal or marginal situations, and (3) growing extra biofuel crop while increasing benefit to field and ecosystem services. Simulation models can assist in the selection process. The USDA's Cropland Data Layer is a data repository containing research on land use and land cover; however, non-agricultural land use cover has a low classification accuracy, although the newest datasets are improved by the use of more advanced technologies [104]. Thompson et al. [146] used the SWAT model to simulate upland and lowland cultivars in several U.S. locations and then tested against field trials. They were able to predict potential switchgrass growth potential with a good fit, especially for lowland cultivars. Using a closely related modelling software called ALMANAC, they were able to acquire and account for parameters including climate, soil, latitude, precipitation, and elevation. A similar simulation was produced by Brown et al. [4] in which atmospheric carbon dioxide levels were altered to predict switchgrass growth potential with climate change considered. They even calculated different management scenarios, soil erosion, and runoff. The use 
of simulations can inform decisions of land managers when selecting cultivars of native grasses and where to plant them.

In any case, the main consideration for feasibility is the site. Fields in the Great Lakes or the Southern Great Plains should choose a different variety of switchgrass, or depending on the grower's goals, a grass mixture may be better. The difference between these sites includes growing degree days, solar radiation, precipitation, snowfall, humidity, temperature, soil, and climate effects such as frequency of drought. Each species or variety has been equipped with characteristics that make it more or less suited to the site. Flooded sites may do well with eastern gamagrass (Tripsacum dactyloides) or lowland switchgrass as they have aerenchyma to help the roots breathe in flooded conditions. Drought prone full sun sites may do better with a mixture as some grasses tolerate degrees of dryness differently. There is also the landscape mosaic to consider if the site is in a vital wildlife location, or near water. Once plants have been chosen that are feasible to grow at the site, the growers will consider environmental benefits, economic return, and supply chain to determine how native perennial grass biofuels can benefit their plans.

\section{Discussion}

Biofuels have great promise as a benefit for growers, the economy, and wildlife if grown responsibly. Highly productive native plants, when grown on marginal lands, can improve wildlife habitat, to sustain soils, and reduce runoff thus improving water quality of adjacent waterways. Native perennial grasses sequester carbon and cultivating them can create a carbon sink in the soil. Wildlife benefit more by having native perennial grass instead of annual crops. Economically, growing native perennial grasses can be advantageous to growers when grown on marginal land, where they can have relatively high yields. While the second-generation biofuel supply chain is most susceptible to changing market prices, it can be made more resilient and has other advantages, including greater resistance to drought impacts. There are many cultivars/ecotypes to choose from. Thus, factors including climate, soil, and genetics provide pertinent information to match each specimen's ideal growing conditions to the right location.

Additionally, the future looks bright for the biofuel industry. The Energy Information Administration anticipates that production of biofuels within the US increasing through 2050 [147]. As of 2020, the federal goal was to produce 90 gallons of ethanol per ton of cellulosic feedstock, including switchgrass as well as crop residues and wood products. Although the maximum amount of energy crops available in 2020-2025 was 147 million tons, that is projected to increase to 368 million tons by the 2050s [126]. Ongoing research from Aranguen et al. [145] showed potential for utilizing biomass from switchgrass in coal-fired power plants, decreasing greenhouse gas emissions, and creating jobs. Using a hybrid simulation model to design a supply chain, they found that a $20 \%$ co-firing rate was attainable at investment costs comparable to coal [145]. Biofuels are not the world's only effort to reduce carbon emissions; it has some competition with technologies such as electric cars, hydrogen power, or reliance on carbon capture [148]. Rejoining the Paris Climate Agreement, increased support for vehicles powered by renewable energy, and pending legislation that would improve the ease of selling and using biofuels are potential boons to the industry. Much depends on the new administration's stances and subsequent implementations [149].

Most biofuel-related policies have come from the federal level, although over half of states also have some incentives for biofuel use. For example, the Renewable Fuel Standard program ensures that all gasoline sold in the US contains some amount of renewably sourced fuel, mostly maize-based, although lignocellulosic fuels are eligible too. The federal government has also incentivized the use of biofuels with tax credits, import duties on biofuels from abroad, as well as direct payments to producers and manufacturers [5]. Often regulations regarding biofuels, are more voluntary than imposed. For example, the Roundtable on Sustainable Biomaterials is a membership-based independent organization that standardizes and certifies biofuels. Because they are not government affiliated they 
use incentives and voluntary measures to encourage biofuel use [150]. These policies have impacts on the environment and economy and on the lives of producers and consumers. For instance, net farm incomes went up due to the high price of biofuels, but it also increased food prices [5]. The U.S. Department of Commerce has stated that an assessment of benefits will become more accurate as more information is understood about factors such as emissions benefits and transition costs [126].

Gaps in system-based biofuel research have been greatly reduced in the last 30 years. Process-based models such as ALMANAC have been developed for the biofuel feedstock currently considered most promising, including perennial grasses, oilseeds, and woody perennials. This model, linked with other system-based tools as described above, has proved useful for determining sites for biofuel production and size of areas to supply adequate amounts of feedstock in wet, dry, and normal rainfall conditions and on various soils. Future research needs include parameterization of additional biofuel feedstock plant types and species as interest in such arises. Likewise, as society's priorities change relative to bioenergy, these system-based tools should be employed to determine feasibility of various scenarios and to quantify environmental and economic impacts.

Climate change and its impacts on plant productivity including these biofeedstocks, remains a controversial yet fascinating field for future research. System-based tools, as described herein, offer great promise for predicting potential changes in biofeedstock productivity with changes in temperature, $\mathrm{CO}_{2}$, and rainfall. Future research applying these tools is the most efficient method of quantifying biofeedstock productivity under potential future climate conditions.

Author Contributions: Conceptualization, J.R.K., J.J. and A.S.W.; Methodology, J.J. and A.S.W.; Formal analysis, J.J. and A.S.W.; Investigation, J.J. and A.S.W.; Data curation, J.J. and A.S.W.; Writingoriginal draft preparation, J.J. and A.S.W.; Writing-review and editing, J.R.K., J.J. and A.S.W.; Supervision, J.R.K.; Funding acquisition, J.R.K. All authors have read and agreed to the published version of the manuscript.

Funding: This work was conducted as part of the activities of the USDA Natural Resources Conservation Service Conservation Effects Assessment Project (NRCS-CEAP), Interagency Reimbursable Agreement \#60-3098-5-006. This research was supported in part by an appointment to the Agricultural Research Service (ARS) Research Participation Program administered by the Oak Ridge Institute for Science and Education (ORISE) through an interagency agreement between the U.S. Department of Energy (DOE) and the U.S. Department of Agriculture (USDA), Agricultural Research Service Agreement \#60-3098-0-002.

Conflicts of Interest: The authors declare no conflict of interest.

\section{References}

1. Guo, M.; Song, W.; Buhain, J. Bioenergy and biofuels: History, status, and perspective. Renew. Sustain. Energy Rev. 2015, 42, 712-725. [CrossRef]

2. Ayadi, M.; Sarma, S.J.; Pachapur, V.L.; Brar, S.K.; Cheikh, R. Ben History and global policy of biofuels. In Green Energy and Technology; Springer: Cham, Switzerland, 2016; pp. 1-14. ISBN 9783319302034.

3. McLaughlin, S.B.; Kiniry, J.R.; Taliaferro, C.M.; De, D.; Ugarte, L.T. Projecting Yield and Utilization Potential of Switchgrass as an Energy Crop. Adv. Agron. 2006, 90, 267-297. [CrossRef]

4. Brown, R.A.; Rosenberg, N.J.; Hays, C.J.; Easterling, W.E.; Mearns, L.O. Potential production and environmental effects of switchgrass and traditional crops under current and greenhouse-altered climate in the central United States: A simulation study. Agric. Ecosyst. Environ. 2000, 78, 31-47. [CrossRef]

5. Adusumilli, N.C.; Adusumilli, N.; Leidner, A. The U.S. Biofuel Policy: Review of Economic and Environmental Implications. Am. J. Environ. Prot. 2014, 2, 64-70. [CrossRef]

6. Liu, H.; Bi, X.; Huo, M.; Lee, C.F.F.; Yao, M. Soot Emissions of Various Oxygenated Biofuels in Conventional Diesel Combustion and Low-Temperature Combustion Conditions. Energy Fuels 2012, 26, 1900-1911. [CrossRef]

7. Gelfand, I.; Snapp, S.S.; Robertson, G.P. Energy efficiency of conventional, organic, and alternative cropping systems for food and fuel at a site in the U.S. Midwest. Environ. Sci. Technol. 2010, 44, 4006-4011. [CrossRef]

8. Fargione, J.E.; Cooper, T.R.; Flaspohler, D.J.; Hill, J.; Lehman, C.; McCoy, T.; McLeod, S.; Nelson, E.J.; Oberhauser, K.S.; Tilman, D. Bioenergy and wildlife: Threats and opportunities for grassland conservation. Bioscience 2009, 59, 767-777. [CrossRef] 
9. Quinn, L.D.; Culley, T.M.; Stewart, J.R. Genetic comparison of introduced and native populations of Miscanthus sinensis (Poaceae), a potential bioenergy crop. Grassl. Sci. 2012, 58, 101-111. [CrossRef]

10. Schnitzler, A.; Essl, F. From horticulture and biofuel to invasion: The spread of Miscanthus taxa in the USA and Europe. Weed Res. 2015, 55, 221-225. [CrossRef]

11. Wilson, H.M.; Cruse, R.M.; Burras, C.L. Perennial grass management impacts on runoff and sediment export from vegetated channels in pulse flow runoff events. Biomass Bioenergy 2011, 35, 429-436. [CrossRef]

12. Meehan, T.D.; Gratton, C.; Diehl, E.; Hunt, N.D.; Mooney, D.F.; Ventura, S.J.; Barham, B.L.; Jackson, R.D. Ecosystem-service tradeoffs associated with switching from annual to perennial energy crops in Riparian zones of the US Midwest. PLoS ONE 2013, 8, e80093. [CrossRef]

13. Gu, Y.; Wylie, B.K. Using satellite vegetation and compound topographic indices to map highly erodible cropland buffers for cellulosic biofuel crop developments in eastern Nebraska, USA. Ecol. Indic. 2016, 60, 64-70. [CrossRef]

14. Landis, D.A.; Gratton, C.; Jackson, R.D.; Gross, K.L.; Duncan, D.S.; Liang, C.; Meehan, T.D.; Robertson, B.A.; Schmidt, T.M.; Stahlheber, K.A.; et al. Biomass and biofuel crop effects on biodiversity and ecosystem services in the North Central US. Biomass Bioenergy 2018, 114, 18-29. [CrossRef]

15. Mishra, S.K.; Negri, M.C.; Kozak, J.; Cacho, J.F.; Quinn, J.; Secchi, S.; Ssegane, H. Valuation of ecosystem services in alternative bioenergy landscape scenarios. GCB Bioenergy 2019, 11, 748-762. [CrossRef]

16. Fletcher, R.J.; Robertson, B.A.; Evans, J.; Doran, P.J.; Alavalapati, J.R.R.; Schemske, D.W. Biodiversity conservation in the era of biofuels: Risks and opportunities. Front. Ecol. Environ. 2010, 9, 161-168. [CrossRef]

17. Meehana, T.D.; Hurlbert, A.H.; Gratton, C. Bird communities in future bioenergy landscapes of the Upper Midwest. Proc. Natl. Acad. Sci. USA 2010, 107, 18533-18538. [CrossRef] [PubMed]

18. Robertson, B.A.; Rice, R.A.; Scott Sillett, T.; Ribic, C.A.; Babcock, B.A.; Landis, D.A.; Herkert, J.R.; Fletcher, R.J.; Fontaine, J.J.; Doran, P.J.; et al. Are agrofuels a conservation threat or opportunity for grassland birds in the United States? Condor 2012, 114, 679-688. [CrossRef]

19. Núñez-Regueiro, M.M.; Siddiqui, S.F.; Fletcher, R.J. Effects of bioenergy on biodiversity arising from land-use change and crop type. Conserv. Biol. 2021, 35, 77-87. [CrossRef] [PubMed]

20. Kremen, C.; Miles, A. Ecosystem services in biologically diversified versus conventional farming systems: Benefits, externalities, and trade-offs. Ecol. Soc. 2012, 17. [CrossRef]

21. Robertson, B.A.; Doran, P.J.; Loomis, L.R.; Robertson, J.R.; Schemske, D.W. Perennial biomass feedstocks enhance avian diversity. GCB Bioenergy 2011, 3, 235-246. [CrossRef]

22. Werling, B.P.; Dickson, T.L.; Isaacs, R.; Gaines, H.; Gratton, C.; Gross, K.L.; Liere, H.; Malmstrom, C.M.; Meehan, T.D.; Ruan, L.; et al. Perennial grasslands enhance biodiversity and multiple ecosystem services in bioenergy landscapes. Proc. Natl. Acad. Sci. USA 2014, 111, 1652-1657. [CrossRef] [PubMed]

23. Scheffran, J.; BenDor, T. Bioenergy and land use: A spatial-agent dynamic model of energy crop production in Illinois. Int. J. Environ. Pollut. 2009, 39, 4-27. [CrossRef]

24. Johnson, J.M.F.; Barbour, N.W. Nitrous Oxide Emission and Soil Carbon Sequestration from Herbaceous Perennial Biofuel Feedstocks. Soil Sci. Soc. Am. J. 2016, 80, 1057-1070. [CrossRef]

25. Strickland, M.S.; Leggett, Z.H.; Sucre, E.B.; Bradford, M.A. Biofuel intercropping effects on soil carbon and microbial activity. Ecol. Appl. 2015, 25, 140-150. [CrossRef]

26. Bandaru, V.; Izaurralde, R.C.; Manowitz, D.; Link, R.; Zhang, X.; Post, W.M. Soil Carbon Change and Net Energy Associated with Biofuel Production on Marginal Lands: A Regional Modeling Perspective. J. Environ. Qual. 2013, 42, 1802-1814. [CrossRef] [PubMed]

27. Haney, R.L.; Kiniry, J.R.; Johnson, M.V.V. Soil microbial activity under different grass species: Underground impacts of biofuel cropping. Agric. Ecosyst. Environ. 2010, 139. [CrossRef]

28. Tiemann, L.K.; Grandy, A.S. Mechanisms of soil carbon accrual and storage in bioenergy cropping systems. GCB Bioenergy 2015, 7. [CrossRef]

29. Sprunger, C.D.; Oates, L.G.; Jackson, R.D.; Robertson, G.P. Plant community composition influences fine root production and biomass allocation in perennial bioenergy cropping systems of the upper Midwest, USA. Biomass Bioenergy 2017, 105. [CrossRef]

30. Ferchaud, F.; Vitte, G.; Mary, B. Changes in soil carbon stocks under perennial and annual bioenergy crops. GCB Bioenergy 2016, 8 . [CrossRef]

31. Das, A.; Lal, R.; Somireddy, U.; Bonin, C.; Verma, S.; Rimal, B.K. Changes in soil quality and carbon storage under biofuel crops in central Ohio. Soil Res. 2016, 54. [CrossRef]

32. Kantola, I.B.; Masters, M.D.; DeLucia, E.H. Soil particulate organic matter increases under perennial bioenergy crop agriculture. Soil Biol. Biochem. 2017, 113. [CrossRef]

33. Bonin, C.L.; Lal, R. Aboveground productivity and soil carbon storage of biofuel crops in Ohio. GCB Bioenergy 2014, 6. [CrossRef]

34. Zenone, T.; Gelfand, I.; Chen, J.; Hamilton, S.K.; Robertson, G.P. From set-aside grassland to annual and perennial cellulosic biofuel crops: Effects of land use change on carbon balance. Agric. For. Meteorol. 2013, 182-183, 1-12. [CrossRef]

35. Woli, K.P.; David, M.B.; Darmody, R.G.; Mitchell, C.A.; Smith, C.M. Assessing the nitrous oxide mole fraction of soils from perennial biofuel and corn-soybean fields. Agric. Ecosyst. Environ. 2010, 138. [CrossRef] 
36. Kwon, H.Y.; Mueller, S.; Dunn, J.B.; Wander, M.M. Modeling state-level soil carbon emission factors under various scenarios for direct land use change associated with United States biofuel feedstock production. Biomass Bioenergy 2013, 55. [CrossRef]

37. Khanna, M.; Önal, H.; Dhungana, B.; Wander, M. Economics of herbaceous bioenergy crops for electricity generation: Implications for greenhouse gas mitigation. Biomass Bioenergy 2011, 35. [CrossRef]

38. Anderson-Teixeira, K.J.; Masters, M.D.; Black, C.K.; Zeri, M.; Hussain, M.Z.; Bernacchi, C.J.; DeLucia, E.H. Altered Belowground Carbon Cycling Following Land-Use Change to Perennial Bioenergy Crops. Ecosystems 2013, 16. [CrossRef]

39. Zhu, X.; Liang, C.; Masters, M.D.; Kantola, I.B.; DeLucia, E.H. The impacts of four potential bioenergy crops on soil carbon dynamics as shown by biomarker analyses and DRIFT spectroscopy. GCB Bioenergy 2018, 10. [CrossRef]

40. Szymanski, L.M.; Sanford, G.R.; Heckman, K.A.; Jackson, R.D.; Marín-Spiotta, E. Conversion to bioenergy crops alters the amount and age of microbially-respired soil carbon. Soil Biol. Biochem. 2019, 128. [CrossRef]

41. Sanderson, M.A.; Adler, P.R.; Boateng, A.A.; Casler, M.D.; Sarath, G. Switchgrass as a biofuels feedstock in the USA. Can. J. Plant Sci. 2006, 86, 1315-1325. [CrossRef]

42. Fornara, D.A.; Tilman, D. Plant functional composition influences rates of soil carbon and nitrogen accumulation. J. Ecol. 2008, 96. [CrossRef]

43. Hunt, N.D.; Gower, S.T.; Nadelhoffer, K.; Lajtha, K.; Townsend, K.; Brye, K.R. Validation of an agroecosystem process model (AGRO-BGC) on annual and perennial bioenergy feedstocks. Ecol. Model. 2016, 321, 23-34. [CrossRef]

44. Hudiburg, T.W.; Wang, W.; Khanna, M.; Long, S.P.; Dwivedi, P.; Parton, W.J.; Hartman, M.; Delucia, E.H. Impacts of a 32-billiongallon bioenergy landscape on land and fossil fuel use in the US. Nat. Energy 2016, 1, 15005. [CrossRef]

45. Jones, C.D.; Oates, L.G.; Robertson, G.P.; Izaurralde, R.C. Perennialization and Cover Cropping Mitigate Soil Carbon Loss from Residue Harvesting. J. Environ. Qual. 2018, 47. [CrossRef] [PubMed]

46. Abraha, M.; Gelfand, I.; Hamilton, S.K.; Chen, J.; Robertson, G.P. Carbon debt of field-scale conservation reserve program grasslands converted to annual and perennial bioenergy crops. Environ. Res. Lett. 2019, 14. [CrossRef]

47. Adkins, J.; Jastrow, J.D.; Morris, G.P.; de Graaff, M.A. Effects of fertilization, plant species, and intra-specific diversity on soil carbon and nitrogen in biofuel cropping systems after five growing seasons. Biomass Bioenergy 2019, 130. [CrossRef]

48. Sticklen, M.B. Expediting the biofuels agenda via genetic manipulations of cellulosic bioenergy crops. Biofuels Bioprod. Biorefin. 2009, 3, 448-455. [CrossRef]

49. Zeri, M.; Hussain, M.Z.; Anderson-Teixeira, K.J.; Delucia, E.; Bernacchi, C.J. Water use efficiency of perennial and annual bioenergy crops in central Illinois. J. Geophys. Res. Biogeosci. 2013, 118. [CrossRef]

50. Gauder, M.; Billen, N.; Zikeli, S.; Laub, M.; Graeff-Hönninger, S.; Claupein, W. Soil carbon stocks in different bioenergy cropping systems including subsoil. Soil Tillage Res. 2016, 155. [CrossRef]

51. Abraha, M.; Hamilton, S.K.; Chen, J.; Robertson, G.P. Ecosystem carbon exchange on conversion of Conservation Reserve Program grasslands to annual and perennial cropping systems. Agric. For. Meteorol. 2018, 253-254, 151-160. [CrossRef]

52. Lal, R. Soil quality impacts of residue removal for bioethanol production. Soil Tillage Res. 2009, 102. [CrossRef]

53. Pawlowski, M.N.; Crow, S.E.; Meki, M.N.; Kiniry, J.R.; Taylor, A.D.; Ogoshi, R.; Youkhana, A.; Nakahata, M. Field-based estimates of global warming potential in bioenergy systems of Hawaii: Crop choice and deficit irrigation. PLoS ONE 2017, 12. [CrossRef]

54. Follett, R.F.; Vogel, K.P.; Varvel, G.E.; Mitchell, R.B.; Kimble, J. Soil Carbon Sequestration by Switchgrass and No-Till Maize Grown for Bioenergy. Bioenergy Res. 2012, 5. [CrossRef]

55. Garten, C.T.; Brice, D.J.; Castro, H.F.; Graham, R.L.; Mayes, M.A.; Phillips, J.R.; Post, W.M.; Schadt, C.W.; Wullschleger, S.D.; Tyler, D.D.; et al. Response of "Alamo" switchgrass tissue chemistry and biomass to nitrogen fertilization in West Tennessee, USA. Agric. Ecosyst. Environ. 2011, 140. [CrossRef]

56. Duval, B.D.; Hartman, M.; Marx, E.; Parton, W.J.; Long, S.P.; DeLucia, E.H. Biogeochemical consequences of regional land use change to a biofuel crop in the southeastern United States. Ecosphere 2015, 6. [CrossRef]

57. Dell, C.J.; Gollany, H.T.; Adler, P.R.; Skinner, R.H.; Polumsky, R.W. Implications of Observed and Simulated Soil Carbon Sequestration for Management Options in Corn-based Rotations. J. Environ. Qual. 2018, 47. [CrossRef]

58. Fazio, S.; Monti, A. Life cycle assessment of different bioenergy production systems including perennial and annual crops Biomass Bioenergy 2011, 35. [CrossRef]

59. Harris, Z.M.; Spake, R.; Taylor, G. Land use change to bioenergy: A meta-analysis of soil carbon and GHG emissions. Biomass Bioenergy 2015, 82, 27-39. [CrossRef]

60. Silveira, M.L.; Brandani, C.B.; Kohmann, M.M.; Erickson, J.E.; Reyes-Cabrera, J.; Leon, R.G.; Sollenberger, L.E.; Piotto, V.; Quadros, D.G.; Mello, S.Q.S. Short-term effects of bioenergy cropping on soil carbon and nitrogen dynamics in a Florida Ultisol. Soil Sci. Soc. Am. J. 2020, 84. [CrossRef]

61. Chatterjee, A.; Long, D.S.; Pierce, F.J. Switchgrass Influences on Soil Biogeochemical Processes in the Dryland Region of the Pacific Northwest. Commun. Soil Sci. Plant Anal. 2013, 44. [CrossRef]

62. Monti, A.; Barbanti, L.; Zatta, A.; Zegada-Lizarazu, W. The contribution of switchgrass in reducing GHG emissions. GCB Bioenergy 2012, 4. [CrossRef]

63. Valdez, Z.P.; Hockaday, W.C.; Masiello, C.A.; Gallagher, M.E.; Philip Robertson, G. Soil Carbon and Nitrogen Responses to Nitrogen Fertilizer and Harvesting Rates in Switchgrass Cropping Systems. Bioenergy Res. 2017, 10. [CrossRef]

64. Nocentini, A.; Monti, A. Land-use change from poplar to switchgrass and giant reed increases soil organic carbon. Agron. Sustain. Dev. 2017, 37. [CrossRef] 
65. Dufossé, K.; Ben Aoun, W.; Gabrielle, B. Life-Cycle Assessment of Agricultural Feedstock for Biorefineries. In Life-Cycle Assessment of Biorefineries; Elsevier: Amsterdam, The Netherlands, 2017.

66. Blanco-Canqui, H.; Laird, D.A.; Heaton, E.A.; Rathke, S.; Acharya, B.S. Soil carbon increased by twice the amount of biochar carbon applied after 6 years: Field evidence of negative priming. GCB Bioenergy 2020, 12. [CrossRef]

67. Hudiburg, T.W.; Davis, S.C.; Parton, W.; Delucia, E.H. Bioenergy crop greenhouse gas mitigation potential under a range of management practices. GCB Bioenergy 2015, 7. [CrossRef]

68. Slessarev, E.W.; Nuccio, E.E.; McFarlane, K.J.; Ramon, C.E.; Saha, M.; Firestone, M.K.; Pett-Ridge, J. Quantifying the effects of switchgrass (Panicum virgatum) on deep organic $\mathrm{C}$ stocks using natural abundance $14 \mathrm{C}$ in three marginal soils. GCB Bioenergy 2020, 12. [CrossRef]

69. Kibet, L.C.; Blanco-Canqui, H.; Mitchell, R.B.; Schacht, W.H. Root biomass and soil carbon response to growing perennial grasses for bioenergy. Energy. Sustain. Soc. 2015, 6. [CrossRef]

70. Zaibon, S.; Anderson, S.H.; Veum, K.S.; Haruna, S.I. Soil thermal properties affected by topsoil thickness in switchgrass and row crop management systems. Geoderma 2019, 350. [CrossRef]

71. Sprunger, C.D.; Philip Robertson, G. Early accumulation of active fraction soil carbon in newly established cellulosic biofuel systems. Geoderma 2018, 318. [CrossRef]

72. Qin, Z.; Dunn, J.B.; Kwon, H.; Mueller, S.; Wander, M.M. Soil carbon sequestration and land use change associated with biofuel production: Empirical evidence. GCB Bioenergy 2016, 8. [CrossRef]

73. Blanco-Canqui, H. Crop Residue Removal for Bioenergy Reduces Soil Carbon Pools: How Can We Offset Carbon Losses? Bioenergy Res. 2013, 6, 358-371. [CrossRef]

74. Tian, S.; Youssef, M.A.; Chescheir, G.M.; Skaggs, R.W.; Cacho, J.; Nettles, J. Development and preliminary evaluation of an integrated field scale model for perennial bioenergy grass ecosystems in lowland areas. Environ. Model. Softw. 2016, 84. [CrossRef]

75. McLaughlin, S.B.; Walsh, M.E. Evaluating environmental consequences of producing herbaceous crops for bioenergy. Biomass Bioenergy 1998, 14. [CrossRef]

76. Blanco-Canqui, H. Growing Dedicated Energy Crops on Marginal Lands and Ecosystem Services. Soil Sci. Soc. Am. J. 2016, 80. [CrossRef]

77. Uden, D.R.; Allen, C.R.; Mitchell, R.B.; Mccoy, T.D.; Guan, Q. Predicted avian responses to bioenergy development scenarios in an intensive agricultural landscape. GCB Bioenergy 2015, 7, 717-726. [CrossRef]

78. Robertson, B.A.; Landis, D.A.; Sillett, T.S.; Loomis, E.R.; Rice, R.A. Perennial Agroenergy Feedstocks as En Route Habitat for Spring Migratory Birds. Bioenergy Res. 2013, 6. [CrossRef]

79. Conkling, T.J.; Belant, J.L.; DeVault, T.L.; Martin, J.A. Effects of crop type and harvest on nest survival and productivity of dickcissels in semi-natural grasslands. Agric. Ecosyst. Environ. 2017, 240. [CrossRef]

80. Homyack, J.A.; Aardweg, Z.; Gorman, T.A.; Chalcraft, D.R. Initial effects of woody biomass removal and intercropping of switchgrass (panicum virgatum) on herpetofauna in eastern North Carolina. Wildl. Soc. Bull. 2013, 37, 327-335. [CrossRef]

81. Roth, A.M.; Sample, D.W.; Ribic, C.A.; Paine, L.; Undersander, D.J.; Bartelt, G.A. Grassland bird response to harvesting switchgrass as a biomass energy crop. Biomass Bioenergy 2005, 28. [CrossRef]

82. Robertson, B.A.; Doran, P.J.; Loomis, E.R.; Robertson, J.R.; Schemske, D.W. Avian use of perennial biomass feedstocks as post-breeding and migratory stopover habitat. PLOS ONE 2011, 6. [CrossRef]

83. Helms, J.A.; Roeder, K.A.; Ijelu, S.E.; Ratcliff, I.; Haddad, N.M. Bioenergy landscapes drive trophic shifts in generalist ants. J. Anim. Ecol. 2021, 90. [CrossRef]

84. Helms, J.A.; Ijelu, S.E.; Wills, B.D.; Landis, D.A.; Haddad, N.M. Ant biodiversity and ecosystem services in bioenergy landscapes. Agric. Ecosyst. Environ. 2020, 290, 106780. [CrossRef]

85. Lee, M.B.; Campbell, J.W.; Martin, J.A. Effect of bioenergy crop type and harvest frequency on beneficial insects. Agric. Ecosyst. Environ. 2018, 261, 25-32. [CrossRef]

86. U.S. Fish and Wildlife Service. Critical Habitat under the Endangered Species Act. U.S. Fish \& Wildlife Service. Available online: https:// www.fws.gov/southeast/endangered-species-act/critical-habitat/ (accessed on 30 June 2021).

87. Sahoo, G.; Wani, A. Impact of Biofuel Production on Biodiversity: A Review. Available online: https://www.researchgate.net/ publication/352689427_IMPACT_OF_BIOFUEL_PRODUCTION_ON_BIODIVERSITY_A_REVIEW (accessed on 7 June 2021).

88. Khanna, M.; Wang, W.; Hudiburg, T.W.; Delucia, E.H. The social inefficiency of regulating indirect land use change due to biofuels. Nat. Commun. 2017, 8, 1-9. [CrossRef] [PubMed]

89. Bowyer, C.; Kretschmer, B. Anticipated Indirect Land Use Change Associated with Expanded Use of Biofuels and Bioliquids in the EU-An Analysis of the National Renewable Energy Action Plans; Institute for European Environmental Policy: Brussels, Belgium, 2011.

90. Solomon, B.D. Biofuels and sustainability. Ann. N. Y. Acad. Sci. 2010, 1185, 119-134. [CrossRef] [PubMed]

91. Wright, C.K.; Wimberly, M.C. Recent land use change in the Western Corn Belt threatens grasslands and wetlands. Proc. Natl. Acad. Sci. USA 2013, 110, 4134-4139. [CrossRef]

92. Mladenoff, D.J.; Sahajpal, R.; Johnson, C.P.; Rothstein, D.E. Recent land use change to agriculture in the U.S. Lake States: Impacts on cellulosic biomass potential and natural lands. PLoS ONE 2016, 11, e0148566. [CrossRef] [PubMed]

93. Deen, B. Biomass for Biofuel: Understanding the risks and opportunities for Ontario agriculture. Can. J. Plant Sci. 2017, 97, 964-971. [CrossRef] 
94. Schilling, K.E.; Jha, M.K.; Zhang, Y.K.; Gassman, P.W.; Wolter, C.F. Impact of land use and land cover change on the water balance of a large agricultural watershed: Historical effects and future directions. Water Resour. Res. 2008, 45. [CrossRef]

95. Marra, M.; Keene, T.; Skousen, J.; Griggs, T. Switchgrass Yield on Reclaimed Surface Mines for Bioenergy Production. J. Environ. Qual. 2013, 42. [CrossRef]

96. Abraha, M.; Chen, J.; Hamilton, S.K.; Robertson, G.P. Long-term evapotranspiration rates for rainfed corn versus perennial bioenergy crops in a mesic landscape. Hydrol. Process. 2020, 34, 810-822. [CrossRef]

97. Acharya, B.S.; Blanco-Canqui, H.; Mitchell, R.B.; Cruse, R.; Laird, D. Dedicated Bioenergy Crops and Water Erosion. J. Environ. Qual. 2019, 48, 485-492. [CrossRef]

98. Davis, S.C.; Parton, W.J.; Del Grosso, S.J.; Keough, C.; Marx, E.; Adler, P.R.; Delucia, E.H. Impact of second-generation biofuel agriculture on greenhouse-gas emissions in the corn-growing regions of the US. Front. Ecol. Environ. 2012, 10, 69-74. [CrossRef]

99. Simpson, T.W.; Sharpley, A.N.; Howarth, R.W.; Paerl, H.W.; Mankin, K.R. The New Gold Rush: Fueling Ethanol Production while Protecting Water Quality. J. Environ. Qual. 2008, 37. [CrossRef] [PubMed]

100. Graves, R.A.; Pearson, S.M.; Turner, M.G. Landscape patterns of bioenergy in a changing climate: Implications for crop allocation and land-use competition. Ecol. Appl. 2016, 26, 515-529. [CrossRef]

101. Stoof, C.R.; Richards, B.K.; Woodbury, P.B.; Fabio, E.S.; Brumbach, A.R.; Cherney, J.; Das, S.; Geohring, L.; Hansen, J.; Hornesky, J.; et al. Untapped Potential: Opportunities and Challenges for Sustainable Bioenergy Production from Marginal Lands in the Northeast USA. Bioenergy Res. 2015, 8, 482-501. [CrossRef]

102. Liu, W.; Wang, J.; Richard, T.L.; Hartley, D.S.; Spatari, S.; Volk, T.A. Economic and life cycle assessments of biomass utilization for bioenergy products. Biofuels Bioprod. Biorefin. 2017, 11. [CrossRef]

103. Behrman, K.D.; Juenger, T.E.; Kiniry, J.R.; Keitt, T.H. Spatial land use trade-offs for maintenance of biodiversity, biofuel, and agriculture. Landsc. Ecol. 2015, 30. [CrossRef]

104. Pritsolas, J.; Pearson, R. A Cautionary Tale: A Recent Paper's Use of Research Based on the USDA Cropland Data Layer to Assess the Environmental Impacts of Claimed Cropland Expansion. 2020, pp. 1-11. Available online: https://www.google. com.hk/url?sa=t\&rct=j\&q=\&esrc=s\&source=web\&cd=\&ved=2ahUKEwj9xfT73vDxAhW9AZ0JHR-PBCoQFjAAegQIAhAD\& url=https $\% 3 \mathrm{~A} \% 2 \mathrm{~F} \% 2$ Fethanolrfa.org $\% 2$ Fwp-content $\% 2$ Fuploads $\% 2$ F2021\%2F06\%2FSIUE-Rebuttal-on-USDA-CDL-Use.pdf\& usg=AOvVaw2-d50iheqPZzKxY5vbReIk (accessed on 7 June 2021).

105. Evans, S.G.; Kelley, L.C.; Potts, M.D. The potential impact of second-generation biofuel landscapes on at-risk species in the US. GCB Bioenergy 2015, 7. [CrossRef]

106. van der Weijde, T.; Alvim Kamei, C.L.; Torres, A.F.; Vermerris, W.; Dolstra, O.; Visser, R.G.F.; Trindade, L.M. The potential of C4 grasses for cellulosic biofuel production. Front. Plant Sci. 2013, 4, 107. [CrossRef] [PubMed]

107. Gallardo, A.L.C.F.; Bond, A. Investigating the effectiveness of environmental assessment of land use change: A comparative study of the approaches taken to perennial biomass crop planting in São Paulo and England. Biomass Bioenergy 2011, 35, $2285-2297$. [CrossRef]

108. Vance, R.W.; Espiritu, J.F. Biofuel Feedstock Optimization Considering Different Land Cover Scenarios and Watershed Impacts. Ph.D. Thesis, University of Texas at El Paso, El Paso, TX, USA, 2013.

109. Khanna, M.; Chen, X.; Huang, H.; Önal, H. Supply of cellulosic biofuel feedstocks and regional production pattern. Am. J. Agric. Econ. 2011, 93, 473-480. [CrossRef]

110. Minick, K.J.; Strahm, B.D.; Fox, T.R.; Sucre, E.B.; Leggett, Z.H.; Zerpa, J.L. Switchgrass intercropping reduces soil inorganic nitrogen in a young Loblolly Pine plantation located in coastal North Carolina. For. Ecol. Manag. 2014, 319, 161-168. [CrossRef]

111. Eranki, P.L.; Bals, B.; Kim, S.; Dale, B.E. Life cycle assessment of advanced regional biomass processing depots integrated with sustainable cellulosic feedstock landscapes. In Proceedings of the Sustainable Engineering Forum: Core Programming Topic at the 2011 AIChE Annual Meeting, Minneapolis, MN, USA, 16-21 October 2011; Volume 1.

112. Mitchell, R.B.; Schmer, M.R.; Anderson, W.F.; Jin, V.; Balkcom, K.S.; Kiniry, J.; Coffin, A.; White, P. Dedicated Energy Crops and Crop Residues for Bioenergy Feedstocks in the Central and Eastern USA. Bioenergy Res. 2016, 9, 384-398. [CrossRef]

113. Bardhan, S.; Jose, S. The potential for floodplains to sustain biomass feedstock production systems. Biofuels 2012, 3, 575-588 [CrossRef]

114. Acosta, O.; Chaparro-Giraldo, A. Biofuels, food security and transgenic crops. Rev. Salud Pública 2009, 11. [CrossRef]

115. Harding, K.J.; Twine, T.E.; VanLoocke, A.; Bagley, J.E.; Hill, J. Impacts of second-generation biofuel feedstock production in the central U.S. on the hydrologic cycle and global warming mitigation potential. Geophys. Res. Lett. 2016, 43. [CrossRef]

116. Moon, H.S.; Abercrombie, J.M.; Kausch, A.P.; Stewart, C.N. Sustainable use of biotechnology for bioenergy feedstocks. Environ. Manag. 2010, 46, 531-538. [CrossRef] [PubMed]

117. Smith, A.L.; Klenk, N.; Wood, S.; Hewitt, N.; Henriques, I.; Yan, N.; Bazely, D.R. Second generation biofuels and bioinvasions: An evaluation of invasive risks and policy responses in the United States and Canada. Renew. Sustain. Energy Rev. 2013, $27,30-42$. [CrossRef]

118. Ale, S.; Femeena, P.V.; Mehan, S.; Cibin, R. Environmental impacts of bioenergy crop production and benefits of multifunctional bioenergy systems. In Bioenergy with Carbon Capture and Storage: Using Natural Resources for Sustainable Development; Elsevier: Amsterdam, The Netherlands, 2019.

119. Jungers, J.M.; Eckberg, J.O.; Betts, K.; Mangan, M.E.; Wyse, D.L.; Sheaffer, C.C. Plant roots and GHG mitigation in native perennial bioenergy cropping systems. GCB Bioenergy 2017, 9, 326-338. [CrossRef] 
120. Prade, T.; Svensson, S.E.; Mattsson, J.E. Energy balances for biogas and solid biofuel production from industrial hemp. Biomass Bioenergy 2012, 40, 36-52. [CrossRef]

121. Tidåker, P.; Sundberg, C.; Öborn, I.; Kätterer, T.; Bergkvist, G. Rotational grass/clover for biogas integrated with grain productionA life cycle perspective. Agric. Syst. 2014, 129, 133-141. [CrossRef]

122. Udawatta, R.P.; Gantzer, C.J.; Reinbott, T.M.; Wright, R.L.; Pierce, R.A.; Wehtje, W. Influence of species composition and management on biomass production in missouri. Agriculture 2020, 10, 75. [CrossRef]

123. Mohapatra, S.; Mishra, C.; Merritt, B.B.; Pattathil, S.; Thatoi, H. Evaluating the Role of Ultrasonication-Assisted Alkali Pretreatment and Enzymatic Hydrolysis on Cellwall Polysaccharides of Pennisetum Grass Varieties as Potential Biofuel Feedstock. ChemistrySelect 2019, 4, 1042-1054. [CrossRef]

124. Sanford, G.R.; Oates, L.G.; Jasrotia, P.; Thelen, K.D.; Robertson, G.P.; Jackson, R.D. Comparative productivity of alternative cellulosic bioenergy cropping systems in the North Central USA. Agric. Ecosyst. Environ. 2016, 216, 344-355. [CrossRef]

125. Liu, T.; Huffman, T.; Kulshreshtha, S.; McConkey, B.; Du, Y.; Green, M.; Liu, J.; Shang, J.; Geng, X. Bioenergy production on marginal land in Canada: Potential, economic feasibility, and greenhouse gas emissions impacts. Appl. Energy $2017,205$. [CrossRef]

126. Osborne, S. Energy in 2020: Assessing the Economic Effects of Commercialization of Cellulosic Ethanol; U.S. Department of Commerce, International Trade A: Washington, DC, USA, 2007; pp. 1-20.

127. Langholtz, M.; Webb, E.; Preston, B.L.; Turhollow, A.; Breuer, N.; Eaton, L.; King, A.W.; Sokhansanj, S.; Nair, S.S.; Downing, M. Climate risk management for the U.S. cellulosic biofuels supply chain. Clim. Risk Manag. 2014, 3, 96-115. [CrossRef]

128. Zhu, X.; Yao, Q. Logistics system design for biomass-to-bioenergy industry with multiple types of feedstocks. Bioresour. Technol. 2011, 102. [CrossRef]

129. Kim, S.; Kim, S.; Cho, J.; Park, S.; Perez, F.X.J.; Kiniry, J.R. Simulated biomass, climate change impacts, and nitrogen management to achieve switchgrass biofuel production at diverse sites in U.S. Agronomy 2020, 10, 503. [CrossRef]

130. Hawkes, C.; Kiniry, J. Legacies in Switchgrass Resistance to and Recovery from Drought Suggest That Good Years Can Sustain Plants Through Bad Years. Bioenergy Res. 2018, 11, 86-94. [CrossRef]

131. Kim, S.; Kim, S.; Kiniry, J.R. Two-phase simulation-based location-allocation optimization of biomass storage distribution. Simul. Model. Pract. Theory 2018, 86, 155-168. [CrossRef]

132. Kim, S.; Dale, B.E. Potential job creation in the cellulosic biofuel industry: The effect of feedstock price. Biofuels Bioprod. Biorefin. 2015, 9. [CrossRef]

133. Uden, D.R.; Mitchell, R.B.; Allen, C.R.; Guan, Q.; McCoy, T.D. The Feasibility of Producing Adequate Feedstock for Year-Round Cellulosic Ethanol Production in an Intensive Agricultural Fuelshed. Bioenergy Res. 2013, 6. [CrossRef]

134. Pearson, C.H.; Larson, S.R.; Keske, C.M.H.; Jensen, K.B. Native grasses for biomass production at high elevations. In Industrial Crops: Breeding for Bioenergy and Bioproducts; Springer: Cham, Switzerland, 2015.

135. Eranki, P.L.; Manowitz, D.H.; Bals, B.D.; Izaurralde, R.C.; Kim, S.; Dale, B.E. The watershed-scale optimized and rearranged landscape design (WORLD) model and local biomass processing depots for sustainable biofuel production: Integrated life cycle assessments. Biofuels Bioprod. Biorefin. 2013, 7. [CrossRef]

136. Barney, J.N. Bioenergy and Invasive Plants: Quantifying and Mitigating Future Risks. Invasive Plant Sci. Manag. 2014, 7, 199-209. [CrossRef]

137. Mitchell, R.; Vogel, K.P.; Uden, D.R. The feasibility of switchgrass for biofuel production. Biofuels 2012, 3, 47-59. [CrossRef]

138. Behrman, K.D.; Kiniry, J.R.; Winchell, M.; Juenger, T.E.; Keitt, T.H. Spatial forecasting of switchgrass productivity under current and future climate change scenarios. Ecol. Appl. 2013, 23, 73-85. [CrossRef]

139. Behrman, K.D.; Keitt, T.H.; Kiniry, J.R. Modeling Differential Growth in Switchgrass Cultivars Across the Central and Southern Great Plains. Bioenergy Res. 2014, 7, 1165-1173. [CrossRef]

140. Kim, S.; Kiniry, J.R.; Williams, A.S.; Meki, N.; Gaston, L.; Brakie, M.; Shadow, A.; Fritschi, F.B.; Wu, Y. Adaptation of C4 bioenergy crop species to various environments within the Southern Great Plains of USA. Sustainability 2017, 9, 89. [CrossRef]

141. Kiniry, J.R.; Johnson, M.V.V.; Bruckerhoff, S.B.; Kaiser, J.U.; Cordsiemon, R.L.; Harmel, R.D. Clash of the Titans: Comparing Productivity Via Radiation Use Efficiency for Two Grass Giants of the Biofuel Field. Bioenergy Res. 2012, 5, 41-48. [CrossRef]

142. Kim, S.; Williams, A.; Kiniry, J.R.; Hawkes, C.V. Simulating diverse native C4 perennial grasses with varying rainfall. J. Arid Environ. 2016, 134, 97-103. [CrossRef]

143. Reichmann, L.G.; Collins, H.P.; Jin, V.L.; Johnson, M.V.V.; Kiniry, J.R.; Mitchell, R.B.; Polley, H.W.; Fay, P.A. Inter-Annual Precipitation Variability Decreases Switchgrass Productivity from Arid to Mesic Environments. Bioenergy Res. 2018, 11, 614-622. [CrossRef]

144. Woli, P.; Paz, J.O.; Lang, D.J.; Baldwin, B.S.; Kiniry, J.R. Soil and Variety Effects on the Energy and Carbon Balances of SwitchgrassDerived Ethanol. J. Sustain. Bioenergy Syst. 2012, 2, 65-74. [CrossRef]

145. Aranguren, M.F.; Castillo-Villar, K.K.; Aboytes-Ojeda, M.; Giacomoni, M.H. Simulation-optimization approach for the logistics network design of biomass co-firing with coal at power plants. Sustainability 2018, 10, 4299. [CrossRef]

146. Thomson, A.M.; César Izarrualde, R.; West, T.O.; Parrish, D.J.; Tyler, D.D.; Williams, J.R. Simulating Potential Switchgrass Production in the United States; U.S. Department of Energy: Washington, DC, USA, 2009. 
147. Shi, E.; Hanson, S. EIA projects U.S. Biofuel Production to Slowly Increase through 2050-Today in Energy-U.S. Energy Information Administration (EIA). Available online: https:/ / www.eia.gov/todayinenergy/detail.php?id=43096 (accessed on 30 June 2021).

148. Connolly, D.; Mathiesen, B.V.; Ridjan, I. A comparison between renewable transport fuels that can supplement or replace biofuels in a 100\% renewable energy system. Energy 2014, 73, 110-125. [CrossRef]

149. Voegele, E. Biomass Leaders Discuss Policy Priorities and Sustainability. Available online: http:/ /www.biomassmagazine.com/ articles /17807/biomass-leaders-discuss-policy-priorities-and-sustainability (accessed on 28 June 2021).

150. Roundtable for Sustainable Biomaterials Home I RSB. Available online: https:/ / rsb.org/ (accessed on 30 June 2021). 